\title{
Farming, Water, Food Sovereignty, and Nutrition in Occupied Palestinian Territories
}

\author{
Susan J. Massad ${ }^{1 *}$, Mohammad Hmidat ${ }^{2}$ \\ ${ }^{1}$ Department of Foods and Nutrition, Framingham State University, 100 State St., Framingham, MA 01701, USA \\ ${ }^{2}$ Quality Assurance Manager, Al Reef for Investment \& Agricultural Marketing, Ramallah - Palestine
}

"Corresponding author: Susan J. Massad, Professor, Foods and Nutrition, Framingham State University, 100 State St., Framingham, MA 01701, USA, E-mail: smassad@framingham.edu

\begin{abstract}
A core Palestinian struggle is safeguarding adequate food and water. Palestine's agricultural economy drastically decreased since the 1967 war. Continued construction of illegal Jewish settlements in the West Bank, and the separation barrier that was erected between Israel and the West Bank create enormous barriers to food sovereignty. One-third of Palestinians suffer from food insecurity. Most communities located in "Area C" (Israeli controlled territory) of the West Bank aren't connected to water networks and have to purchase water at vastly increased costs.

International organizations, like the World Food Programme, the UN Relief and Works Agency, and other groups such as the Palestine Fair Trade Association, Non-Governmental Organizations, and the Boycott, Divestment, and Sanctions campaign, work toward a common goal of enhancing Palestinians' lives in general, and improving the food and agriculture sector in particular.

Better access to the region's nutritious, staple foods that are low on the food chain could readily provide nutritional needs to the Palestinians. A sample menu and nutrition analysis, intended to meet the United Nations Food and Agricultural Organization's minimum daily energy requirement of $1690 \mathrm{kcal}$ per person per day for people in the Occupied Palestinian Territories is provided. If barriers to food access could be removed, food variety could be increased, and food plans meeting this baseline caloric and nutrient requirement would be within reach.
\end{abstract}

Received Date: May 18, 2016
Accepted Date: October 24, 2016
Published Date: October 31, 2016

Citation: Massad, S.J., et al. Farming, Water, Food Sovereignty, and Nutrition in Occupied Palestinian Territories. (2016) Int J Food Nutr Sci 3(2): 359-371.

DOI: $10.15436 / 2377-0619.16 .932$

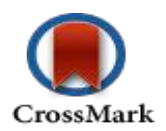

Keywords: Agriculture; Food sovereignty; Palestine; Separation wall; Water rights; Boycott divestment sanctions

\section{Introduction}

Securing an adequate food and water supply without political and economic restrictions is central to the Palestinian struggle. Multinational efforts to dispossess them of their land have threatened food sovereignty, farmers' ability to sustain a living, and the survival of Palestinian people as a whole.

The international peasant movement, La Vie Campesina, introduced the concept of food sovereignty at the International Food Summit in 1996, with a declaration that people must repossess their power in the food system ${ }^{[1]}$. This is best achieved by rebuilding relationships between people and their land, and among food providers and consumers. Food sovereignty diminishes with acquisition of land by force, more commonly known as "land grabbing." This involves taking possession of, or con- trol over, agricultural land for commercial or industrial agricultural production. Such land is disproportionate in size compared to the average land holding in the particular region ${ }^{[2]}$.

Historic land grabbing in Palestine has left Palestinian farmers with enormous obstacles to food and land autonomy. From water use, to transportation, to access to farmland throughout the territories, they face resistance from the occupying Israeli military and from construction and expanding illegal Jewish settlements in the West Bank.

The problem isn't inadequate food production; it's inadequate food access due to poverty, governmental strife, and economic blockades. The agricultural base of developing countries traditionally came from regional natural resources and in-

(7) Copyrights: (C) 2016 Massad, S.J. This is an Open access article distributed under the terms of Creative Commons 
digenous knowledge of food production methods. Traditional agricultural practices in Palestine were sustainable and nurtured biologically and genetically diverse smaller farms $\mathrm{s}^{[3]}$.

Prior to the 1967 war, in which Israel gained sole control of Jerusalem, and set up military administrations in the occupied territories, agriculture comprised approximately $35 \%$ of Palestine's Gross Domestic Product (GDP). By 1993, prior to the Oslo Accords, agriculture made up approximately $13 \%$ of GDP. It is currently about $6 \%$ of GDP ${ }^{[3]}$. The decline is attributed to many factors including Israeli occupation, continued building of illegal settlements in the West Bank, lack of control over the occupants' own water supply, and construction of the separation wall creating a barrier between the West Bank and Israel that blocks Palestinian farmers' access to their own land.

To examine the question of why food sovereignty is limited in the Palestinian territories, this discussion is broken down into: (1) historic events that led to loss of Palestinian land and diminished agriculture (2) food insecurity; (3) the effects of land takeover, settlements, the separation wall, and recent conflicts on traditional farming practices(4) the olive trade, other crops, and uprooting of olive trees(5) access to water resources (6) recent events that affect large agribusiness (7) organizations working on solutions, and (8) meeting basic nutritional needs in Palestine

In chronicling the historic and political influence over food access in Palestine, limited information was available on the nutritional content of staple foods, and how basic nutritional needs could be met if some of the barriers to accessing these basic foods could be alleviated. The United Nations (UN) Food and Agricultural Organization (FAO) has set a Minimum Dietary Energy Requirement (MDER), expressed as kilocalories (kcal) per person per day. The calculation for the Occupied Palestinian Territories (OPT) is $1690 \mathrm{kcal}$ per person per day. This need can be met with better access to indigenous staples like lentils, fish, yogurt, rice, wheat, dates, oranges, various vegetables, and olives.

\section{Background: Historic events that led to loss of Palestinian land and diminished agriculture}

One hundred years ago, most of the world's Arabs lived within the Ottoman Empire. The Sykes-Pico agreement of 1916 led to partition of Turkish-held Syria, Iraq, Lebanon, and Palestine into various French and British mandates. At the end of World War I, the Ottoman Empire collapsed, and Palestine went under British rule.

After the World War II Holocaust, the global Jewish community called for a recognized Jewish state in the region known as the "Holy Land" - between the Jordan River and the Mediterranean Sea. The British government handed over its mandate to the UN in 1946. The UN Partition Plan, or Resolution 181, in 1947, called for the creation of a Jewish and an Arab state, with the internationalization of Jerusalem. Violence between the Jewish and Arab people erupted. More than 700,000 Palestinians were forcibly displaced. Egypt, Syria, and Jordan fought Israel to regain territory. Israel won the war, which left them to work out territorial rights with the Palestinians. Israelis refer to the 1948 war as the "War of Independence" while Palestinians refer to it as "al-Nakba" (the catastrophe).

After this 1948 expulsion, many Palestinian orange and olive groves went unattended. Some landowners attempted to return to gather belongings or harvest what they could from their own fields. The Israeli government considered them "infiltrators," and some were shot on sight. Others returned to find their crops burned. The Israeli Defense forces ordered Jews to harvest the fields and destroy what they were unable to reap ${ }^{[4]}$. Relief officials conveyed increasing alarm over malnourished children whose families had been expelled from their villages and sent to live as refugees in larger cities like Ramallah. The UN mediator and Head of the Swedish Red Cross, Count Folke Bernadotte, requested emergency supplies for Palestine's Arabs. Emergency food was shipped. Bernadotte also advocated for allowing the return of Palestinian refugees. Later that year he was shot and killed by Zionists ${ }^{[5]}$.

More land was lost during the "six-day war" of 1967, between Israel and its Arab neighbors, leaving Israel in sole control of Jerusalem. Over a million Palestinians and hundreds of thousands of refugees in the OPT went under Israeli rule. By the time the UN-brokered ceasefire ended the war, Israel had more than doubled its size. The UN Security Council called for withdrawal from all of the occupied regions, but Israel defied the order, permanently annexing East Jerusalem and setting up military administrations in the OPT. Israel expanded municipal boundaries of the city and gained control of all territory allocated for both the Jewish and the Palestinian state under the terms of the $1947 \mathrm{UN}$ partition plan ${ }^{[6]}$.

The decades-old battle over Palestinian and Israeli territory was supposed to end with the historic Oslo Accords, signed by Israeli Prime Minister Yitzhak Rabin and Palestinian Liberation Organization (PLO) Chairman Yasser Arafat on September 13, 1993. The accords called for a five-year transitional period in which Palestine would support Israel's right to exist and Israel would withdraw its forces from the OPT. After this, negotiators were supposed to determine a final peace agreement and resolve the most challenging issues: final borders, security arrangements, the future of Jerusalem, whether the Palestinians would have an independent state, Jewish settlements in the West Bank and Gaza, and Palestinian refugees' claims to land and property they left behind. Then-foreign Minister Shimon Peres assured the PLO leader Arafat that Palestinian institutions in Jerusalem would be allowed to develop and expand. Israel would withdraw their troops from major population centers.

The Palestinians had no international contract lawyers representing them, which permanently weakened their ability to have any of the accord come to fruition. Also, the "Final Status" agreements relinquished any concrete hope of getting back the lands lost in 1948. Only $27 \%$ of historic Palestine conquered by Israel in 1967 was involved in these negotiations, with no guarantee that Israel would ever give it back ${ }^{[7]}$.

There was no provision to halt construction of Jewish settlements in Palestinian lands. The Palestinian negotiators weren't able to assure that any of the agreements were legally binding. Settlement construction has substantially risen since 1993, decreasing agricultural land and water for Palestinian farmers. Israel's settler population in the OPT more than doubled - from roughly 270,000 in 1993 to over 560,000 by $2013^{[8]}$. The International Middle East Center reported that as of December 31,2015, the number of Israeli settlers in the West Bank and East Jerusalem surpassed 765,000 ${ }^{[9]}$.

Another factor that diminished agriculture was the 2006 elections, in which the Palestinian Islamic organization 
Hamas won a large parliamentary majority, unseating President Mahmoud Abbass's long-dominant Fatah movement. Hamas is deemed a terrorist organization by the United States and Israel. Subsequently, a land, air, and sea blockade was implemented on the Gaza Strip by Israel, with Egypt also keeping its border with Gaza mostly sealed. Before the blockade, wheat, fruit, and fish were exported regularly and provided a source of income in Gaza.

The contribution of agriculture to the economies of both the West Bank and Gaza has continually declined as economic and political policies that hurt farming have intensified. Given the changes in land ownership and infrastructure created by the wars, a long-term solution remains elusive.

\section{Food insecurity}

Associated with global food politics, food sovereignty affects food security and the right to food. Its principles are involved in addressing hunger and malnutrition, and promoting rural development, environmental sustainability, and ecological balance. Globally, the number of undernourished people has continued to increase. Alleviating global hunger and poverty won't be possible without helping small farmers to improve their circumstances $^{[10]}$.

Riyad H. Mansour, Permanent Observer of the State of Palestine, in his 2014 report (UN General Assembly meeting, 69th session, 29th meeting, 4 November 2014) cited the historic confiscation of land and aquifers (underground layers of water-yielding permeable rock), stolen harvests, and denial of access to crops and agricultural land, as parts of a systematic effort to drive Palestinian landowners from their properties, allowing Israelis to take over. Agriculture, once cornerstone of the Palestinian economy, and the "basic pillar of food security," is no longer an economic mainstay ${ }^{[1]}$.

Food insecurity in the OPT is also driven by poverty linked to West Bank occupation and the blockade of the Gaza Strip. According to the Palestinian Central Bureau of Statistics and UN agencies in the food-security sector's 2013 annual food security survey, 33\% (1.6 million) of Palestinian people suffer from food insecurity. Rates are higher in Gaza (57\%) and lower in the West Bank $(19 \%)^{[12]}$.

Risks of malnutrition in the OPT are well documented (FAO of the UN) ${ }^{[13]}$. Continuous territorial conflict has left farmers with fading land and water resources for their crops and animals, creating disproportionate economic obstacles. High costs of fertilizer and animal feed decrease profits, inflate market prices, and keep communities in poverty. Water brought in by tankers costs four-times more than the networked water supply that farmers can't access.

Massad et al (2012) ${ }^{[13]}$ surveyed 1500 students from 22 schools run by the UN Relief and Works Agency (UNRWA) for Palestine Refugees in the Near East and Palestinian Government. Though the percentage of children who had stunted growth or who were underweight (both 7\%) weren't exceptionally high, both were associated with households not having enough food and having at least one parent being unemployed. Radi, El-Sayed, Nofal, \& Abdeen (2013) collected health and socioeconomic data from parents of 733 children in 110 households in Gaza City. Study participants were from urban areas, rural areas, and refugee camps. They found that $92.0 \%$ of households purchased their drinking water from a truck with tanks of filtered water, $97.5 \%$ suffered from electricity shortages, $84.7 \%$ lacked available gas for daily cooking, and $72.7 \%$ reported insufficient income. The total proportion of households living below the poverty line was $92.1 \%$, and $94.4 \%$ faced difficulties with food access. The major causes $(97.3 \%)$ of difficulty accessing food were the siege and shortage of food products on the market, followed by increased food prices (94.0\%) and loss of income $(63.0 \%)$. The most common food items that were lacking were poultry $(73.4 \%)$, fruits and meats $(67.9 \%)$ fish $(64.0 \%)$, eggs $(53.3 \%)$, yogurt and cheese $(50.5 \%)$, and flour and bread $(40.8 \%)$. More than two-thirds $(70.3 \%)$ of the households had to borrow money or use credit to purchase food and to cope with food insecurity, while $42.3 \%$ relied on aid and donations. More than one third (35.1\%) of households reported having to sell gold and $9.4 \%$ to sell assets in order to cope with food insecurity. More than half $(50.6 \%)$ of the preschool children in the study sample were anemic. The overall prevalence of wasting, stunting and underweight was $3.5 \%$ in urban areas, $15.0 \%$ in rural areas, and $6.1 \%$ in refugee camps. Stunting was significantly associated with poverty, food security and birth weight, while underweight was significantly associated with food insecurity.

In December 2013, Palestine and Israel experienced the heaviest snowfall in decades. Torrential rains severely affected various regions in Palestine, particularly Gaza. The World Food Programme (WFP) delivered emergency food rations to families displaced by flooding and storm damage. In Gaza, approximately 10,000 people sought shelter in public buildings and received emergency food rations (canned fish and bread). An additional 1000 people in the West Bank required assistance due to cuts in electricity and infrastructural damages. The WFP reaches approximately 648,000 "food insecure" Palestinians per month ${ }^{[14]}$.

The 51-day Israeli war on Gaza in the summer of 2014 left over half-a-million people (about $30 \%$ of Gaza's population) internally displaced. Many food vendors closed and/or lost their shops during the heavy bombing. The WFP and the UNRWA provided daily, ready-to-eat food rations to the displaced people in UNRWA schools, reaching over 340,000 people ${ }^{[15]}$.

\section{The effects of land takeover, settlements, the separation wall, and recent conflicts on traditional farming practices}

This 1936 description of the land known as Al Ramla, an Arab town of about 11,000 inhabitants situated on the coastal plain between Jerusalem and the Mediterranean, is a reminder of what once was: The soil was good - Arab farmers produced hundreds of thousands of tons of barley, wheat, cabbage, cucumbers, tomatoes, figs, grapes and melons. Oranges, olives, and almonds were grown in a communal waaqf -land owned collectively by the extended family and administered by Islamic law ${ }^{[4]}$.

Some staple foods in Palestine -- olives, za'atar (oregano, thyme, sumac, savory, and sesame seeds), figs, and dates are deeply rooted in the culture and history of the land. They supply nourishment, require little water and upkeep, and are well adapted to the climate. Other locally grown vegetables and fruits are main sources of essential vitamins and minerals.

Small farms that used to be common in Palestine were more sustainable and better for the environment. As more land was taken by Israel after 1967, the use of chemical pesticides, herbicides, and fertilizers provided by Israeli traders, increased in the Palestinian Agricultural sector. Mono cropping (growing a single crop on the same land every year with no rotation through 
other crops - common practice for corn, wheat, and soybeans) increased. Plant diversity in agro-ecosystems provides insurance against soil pests and leads to better crop yield ${ }^{[16]}$. When small farmers are forced to conform to practices that benefit larger-scale industrial farms, they become vulnerable to middlemen who dictate prices and crop varieties. Unable to compete, they often go out of business.

Industrial farming practices use high technology machinery and excessive amounts of water, leading to over-consumption of fossil fuels, soil degradation, and erosion. Conventional food from industrial farms and factories must be transported long distances, requiring additional and sometimes excess packaging, and longer refrigeration.

Smaller farmers can minimize environmental damage by using less pesticide, by composting, and by using "no-till agriculture" (growing crops without "tilling" or agitating the soil). This increases the amount of water that infiltrates soil and increases organic matter retention and the cycling of nutrients. No-till agriculture reduces soil erosion, making it more fertile. Smaller farms are best suited to support farmers' livelihoods and provide nutritious food in Palestine. The Israeli governments' policies aren't the only obstacles to agricultural development. The Palestinian Authority (PA) only allocates 1\% of its annual budget to the agricultural sector. The Palestinian Ministry of Agriculture isn't able to prevent agribusiness products coming from Jewish settlements into local Palestinian markets. A ban on settlement goods, introduced in 2010, is poorly enforced. Even when local seasonal produce from Palestinian farms is available, produce from Israeli agribusinesses often dominates local markets $^{[17]}$.

Full Israeli control of all national borders leaves Palestinian importers and exporters with significant hardships. Two major routes for Palestinian products are via the King Hussein Bridge (KHB) and via some major commercial crossings and then through Israel. The KHB presents hurdles, including long distance travelling, no transit agreement with Jordan, and temperature changes that affect perishable produce. Palestinian cargo can only be transported on cargo planes at limited times and on limited dates, while Israeli cargo can be shipped on both cargo and passenger planes. Palestinian traders are excluded from the cheaper rates and better connections offered by passenger planes, and they aren't allowed to send their harvest directly to ports. They can only use pallets that are less than 160 $\mathrm{cm}$ in height (for security), and have to pay double the usual costs for shipping and insurance. They must pay forklift operators and scanners at the borders, and incur expenses of testing and uploading goods onto Israeli trucks. Fees for Palestinians are tripled. If there are strikes by Israeli port workers, Palestinian goods get pushed to the bottom of the line while preference is given to Israeli products. The Palestinian private sector loses millions of shekels. There is also loss of quality control by Palestinian companies ${ }^{[18]}$.

Vivien Sansour et al (2014) $)^{[19]}$, in Palestinian Farmers, a Last Stronghold of Resistance, explain that in June of 2014, the PA's Ministry of Agriculture, which originally encouraged farmers to plant watermelons with promises to promote and protect their crop, was forced to allow an overflow of cheaply grown watermelons from Israel into the Palestinian market under the protection of the Israeli army. Two Israeli agricultural export companies - Mehadrin and Hadiklaim, significantly benefit from destruction of Palestinian agriculture. Both use the Palestinian water supply and operate inside illegal West Bank settlements from which they export produce.

According to B'Tselem, the Israeli Information Center for Human Rights in the Occupied Territories, more than 530,000 Israeli settlers living in 135 settlements and about 100 outposts in Area C (Israeli controlled), are in contravention of international law. Palestinians aren't permitted to work in Area C, which covers $61 \%$ of the West Bank, severely limiting agriculture $^{[20]}$.

In 2014, despite international condemnation, the Israeli government announced that it would annex 990 acres of Palestinian Territory near the Jewish settlement of Gva'ot, west of Bethlehem. It declared the area 'State Land', paving the way for more settlements considered illegal under international law ${ }^{[21]}$. This further diminishes land available for Palestinian agricultural development, and is compounded by the fact that Palestinian farmers also face land confiscation by the PA. The PA wants to build industrial zones to allegedly help farmers and create jobs. Most farmers fear that these zones will only turn them into laborers instead of productive farmers while stripping them of their land.

Israel's land, air, and sea blockade on the Gaza Strip since 2007 prevents farmers from accessing basic equipment and has made exports of fresh produce nearly impossible. Farmers and fishermen repeatedly come under attack by the Israeli military. The blockade includes prevention of essential equipment for irrigation systems and fishing nets from being imported into Gaza. There are serious limitations on food related exports out of Gaza. Most of the farmland that was previously used to grow fruit, vegetables, and olive and nut trees has been abandoned.

In 2002, the Israeli government authorized construction of a physical barrier - known as the "separation wall," splitting Israel and the West Bank with the intention of controlling the entry of Palestinians from the West Bank into Israel. The average width of the barrier is 60 meters. This significantly impacted farming and agriculture since its construction involved uprooting of many olive groves, and cut off many farmers from their own land. This wall moved out the "green line," separating the land taken by Israel in 1948 and the land occupied in 1967, and was built on some Palestinian farmers' land in Jerusalem ${ }^{[22]}$.

The wall construction left over 15 groundwater wells on the Israeli side. It not only isolated Palestinians from their land, but also increased home demolitions by Israel. Water pipes that couldn't be rerouted with the construction of the wall were destroyed. Water wells for adjacent communities became inaccessible. Cisterns were destroyed. As a result, Palestinians can't access their water and land in the areas behind the wall[23].

The 7-week battle between Israel and Gaza beginning July 8, 2014 ended with a ceasefire agreement on August 26, 2014. It stipulated that Israel would immediately expand the fishing zone off Gaza's coast, allowing fishermen to sail as many as six nautical miles from shore. Part of the agreement was to gradually expand the area. Under the terms of the deal, Israel also agreed to ease its siege on the coastal region. However, since the ceasefire agreement, Palestinian fishermen have reported that Israeli warships fired machine guns at their boats while they were sailing within the agreed-upon six-nautical-mile limit near Rafah ${ }^{[24]}$. 


\section{The olive trade, other crops, and uprooting of olive trees}

As the table below indicates, oranges, olives, vegetables, melons, and other fruits were planted abundantly prior to 1947.

Table 1: Major Crops of Palestine before 1947.

Source: Gavish, D (2005) The Survey of Palestine Under the British Mandate, 1920-1948 (Routledge Studies in Middle Eastern History)

Following is a list showing the major crops of Palestine before 1947 and the portion produced by Jews:

\section{Citrus}

The total area planted with citrus before the British mandated terminated was 281,448 dunums, ( 1 dunum $=1,000$ sq. meters) of which 139,728 dunums were owned by the Jews.

The export of oranges was as follows: -

\begin{tabular}{|l|l|}
\hline Period & Orange boxes exported* \\
\hline $1908-1909$ & 744,463 \\
\hline $1910-1911$ & 869,850 \\
\hline $1912-1913$ & $1,608,570$ \\
\hline $1938-1939$ & $16,000,000$ \\
\hline
\end{tabular}

* A box of citrus on average contained 144 oranges.

\section{Other agricultural products}

The breakdown of the other agricultural production in 1944 is as the following:

\begin{tabular}{|c|c|c|c|c|c|c|c|c|c|}
\hline & \multicolumn{3}{|c|}{ Palestinian } & \multicolumn{3}{|c|}{ Jewish } & \multicolumn{3}{|c|}{ Total } \\
\hline & Dunums & Tons & Value* & Dunums & Tons & Value ${ }^{*}$ & Dunums & Tons & Value ${ }^{*}$ \\
\hline Grains & $4,152,438$ & 193,376 & $4,403,409$ & 215,191 & 16,579 & 497,048 & $4,367,629$ & 209,955 & $4,900,457$ \\
\hline Vegetables & 239,733 & 189,104 & $5,113,553$ & 40,207 & 55,730 & $1,745,870$ & 279,940 & 244,834 & $6,859,423$ \\
\hline Fodder & 23,970 & 20,827 & 156,847 & 119,578 & 176,525 & 951,178 & 143,543 & 197,352 & $1,108,025$ \\
\hline Fruits ${ }^{\star \star}$ & 355,709 & 73,320 & $3,139,374$ & 37,217 & 21,398 & $1,379,620$ & 392,926 & 94,718 & $4,518,994$ \\
\hline Olives & 592,546 & 78,287 & $3,320,320$ & 7,587 & 1,182 & 53,235 & 600,133 & 79,469 & $3,373,555$ \\
\hline Melons & 120,304 & 135,634 & 969,630 & 5,675 & 7,193 & 83,975 & 125,979 & 142,827 & $1,053,605$ \\
\hline Total & $5,484,700$ & 690,548 & $17,103,133$ & 425,455 & 278,607 & $4,710,926$ & $5,910,150$ & 969,155 & $21,814,059$ \\
\hline Percentage & $92.8 \%$ & $71.25 \%$ & $78.40 \%$ & $7.20 \%$ & $28.75 \%$ & $21.60 \%$ & $100 \%$ & $100 \%$ & $100 \%$ \\
\hline
\end{tabular}

Source: Survey of Palestine, prepared by the British Mandate for the United Nations, p. 323-327

* Value in Palestinian Pound

${ }^{* *}$ Non-citrus fruits. Note that Citrus production totaled of 248,274 dunums of which 120,897 dunums were Jewish owned (Supplement to Survey of Palestine, p. 37)

During 1944 - 1945, the area of land planted with olives was 595,405 dunums (0.227 acre), of which the Jews owned only 7,000 dunums or less than $1.2 \%$. In the same years, the amount of olives produced was 75,341 tons. The number of fruitful olives trees was estimated to be $6,000,000$ trees and each tree produced $2 \mathrm{~kg}$ during the drought periods and $12 \mathrm{~kg}$ in the fruitful periods, and an average of $7 \mathrm{~kg}$ per year ${ }^{[25]}$.

Olive oil is the backbone of the Palestinian agricultural economy and crucial to the survival of many Palestinian families. Olive trees, many of which are hundreds of years old, play a major role in the culture and economy. Palestinians regard ancient olive trees as a symbol of resilience and a connection to their land. Olive oil is exported all over the world. The annual olive harvest is the main source of income for about 100,000 farming families. According to the UN Office for the Coordination of Humanitarian Affairs, approximately $48 \%$ of the agricultural land of occupied Palestine is planted with 10 million olive trees, mainly in the West Bank $^{[26]}$. It's estimated that Israelis have destroyed over 800,000 olive trees in the West Bank since 1967.

Dates are another of the region's important crops. Many are planted in the Jordan valley, which is too hot, too dry, and under sea level. With so many restrictions, Palestinians rely more on planting olive trees since these last longer without water. Although Palestine is recognized for olive vines and dates on its hills, it used to be well known for its citrus fruit on its coast. The bulk of the agricultural investment during the British Mandate era was in private sector citrus growing, harvesting, and distribution from the 
western coastal plains. Prior to 1930, in addition to owning the majority of the olive groves, Arabs owned citrus groves and the fruit was a major agricultural export. Jaffa, the largest city in historic Palestine, formerly home to over 80,000 Palestinians, was renowned for its abundant, high-quality oranges. Demand for Jaffa oranges was international, earning the city a place in the global economy. "By the 1930s, Jaffa was exporting tens of millions of citrus crates to the rest of the world, which provided thousands of jobs for the people of the city and its environs, and linking them to the major commercial centers of the Mediterranean coast and the European continent"[27]. Jaffa was the focal point of the Palestinian economy before the 1947 UN Partition. In 1948 the establishment of Israel displaced 95\% of Jaffa's indigenous Arab Palestinians. Citrus fruit is no longer a mainstay of the Palestinian agricultural economy.

Each year during the olive-harvesting season, incidents of uprooting of olive trees intensify across the West Bank. In the first five months of 2015, the UN recorded the uprooting or vandalizing of 8,841 trees by Israeli settlers ${ }^{[28]}$. Press TV reported on April 22, 2014 that Israeli settlers destroyed more than 100 olive trees belonging to Palestinian farmers in the village of Ras Karkar, northwest of Ramallah ${ }^{[29]}$. According to a May 3, 2014 report in The Times of Israel, unknown assailants chopped down 32 olive trees and scrawled racist invectives in the West Bank village of Nahalin ${ }^{[30]}$.

In October 2013, Israeli settlers chopped down over 100 olive trees in Qaryut village, near Nablus. October is peak olive harvest season for Palestine ${ }^{[31]}$. Villagers living south of Nablus reported that Israeli settlers used chemicals last June to burn 1,500 trees there. In the blaze that followed, more than 49 acres of prime agricultural land was destroyed.

On May 19, 2014, the Israeli Defense Forces (IDF) bulldozed 1500 apple and apricot trees at the Tent of Nations near Bethlehem- a renowned Palestinian farm owned by the Nassar family, just a few weeks ahead of their harvest. Owner Daoud Nassar is well known for his commitment to peaceful coexistence between Palestinians and Israelis. Near the front gate to his farm is a stone etched with the words, "We Will Not Be Enemies." Daoud's family owned this 100 -acre farm (known as Daher's Vineyard) since the days of the Ottoman Empire ${ }^{[32]}$.

In April 2014, Israeli settlers uprooted several hundred newly planted grape vines in al-Khader, (south of Bethlehem). Settlers stole the grape vines that were grown on a 10 dunum-sized plot of land that had been recently reclaimed by the Palestinian Agricultural Relief Committees ${ }^{[33]}$. Note: one dunum is equal to $1 / 3$ of an acre.

\section{Access to water resources}

Land grabbing is also motivated by a desire to capture water resources and has implications for both surface water and groundwater. Acquisition of land is useless without existing infrastructure that supplies water ${ }^{[34]}$. Gasteyer, et al, (2012) ${ }^{[35]}$ in their analysis of water grabbing in Palestine in a historical perspective, show that Zionist grabbing of Palestinian land and water resources was largely influenced by politics, ideology and religion. The quest for land and water rose during the British Mandate. In 1922 the Jewish Agency (established under the terms of the British Mandate for Palestine to promote Jewish immigration) formed a technical committee to study of the utilization of water and irrigation. In 1926, the British High Commis- sioner issued a permit to the Jewish-owned Palestine Electricity Corporation to utilize water from the Jordan and Yarmouk rivers to generate electricity. In 1937, Mekerot (Israel's National Water Company) was established by the Zionist labor organization, Histadrut to plan, execute, and run water-works for irrigation and consumption. This increased irrigation and agricultural production - the intent of Zionist leaders and British Mandate officials, as a means of bringing in revenue and extending Jewish acquisition and power over the region.

By 1948 a network was formed to settle new Jewish immigrants and to increase agricultural and industrial development. This included the damming of the Sea of Galilee to divert water to Mekerot. Agriculture was expanded through water extraction throughout southern Israel. Water from the Coastal aquifer and Coastal plain was badly overdrawn and polluted by the $1950 \mathrm{~s}^{[35]}$.

Shortly after the Israeli army captured the West Bank in 1967, military order No. 92 was issued, prohibiting Palestinians from all water development, drilling, and infrastructure building in the West Bank. Presently, Palestinian landowners can only access water from West Bank aquifers by obtaining permits from the Israeli government and they are very difficult to obtain. Permits are seldom issued for agricultural or domestic use in any of the areas that benefit from the region's "Western Aquifer." Although the Occupied Territories have the highest amount of groundwater or potential access to it, the Israeli government authorizes them to use the least amounts within the region. The average per capita total water use in Israel is nearly $344 \mathrm{~m}^{3} /$ year, while it's only $93 \mathrm{~m}^{3} /$ year in Palestine. Domestic per capita water use is estimated at $98 \mathrm{~m}^{3} /$ year in Israel, $56 \mathrm{~m}^{3} /$ year in Jordan, $34 \mathrm{~m}^{3} /$ year in the urban areas in Palestine and as low as $10 \mathrm{~m}^{3} /$ year in some rural areas of Palestine. The actual Palestinian average daily water use in urban areas is estimated at 50 liters/ day, half of what the World Health Organization (WHO) deems necessary to meet basic needs ${ }^{[21]}$.

B'Tselem reports that over $70 \%$ of communities located entirely or mostly in "Area C" (controlled entirely by the Israeli government) are not connected to the water network and rely on "tinkered" water at vastly increased costs. Water consumption in some of these communities is as low as 20 liters per capita per day, one-fifth of the World Health Organization's recommendation ${ }^{[36]}$.

The Oslo Accords allotted $80 \%$ of the water pumped from the mountain aquifer - one of three underground water reserves shared by Israel and the Palestinians - to Israel and only $20 \%$ to Palestinians. There was no cap on Israel's water supply. Palestinians were limited to 118 million cubic meters $(\mathrm{mcm})$ from drilling points active prior to signing of the Accords. Even though Palestinians could obtain the $118 \mathrm{mcm}$ from independent drilling points, only $73 \%$ of that could be attained due to technical limitations of their equipment, the specific properties of the aquifer and its water level, and the failure of U.S. and German-aided attempts to drill for water in the aquifer's eastern basin. Hence, Israel gets $86 \%$ of the aquifer's water and the Palestinians only $14 \%$. Though Israel's national water company Mekorot currently sells Palestinians $53 \mathrm{mcm}$ of water a year - twice the amount stipulated in the Oslo Accords - it doesn't come close to meeting demand ${ }^{[37]}$. 


\section{WATER CONSUMPTION IN ISRAEL, THE WEST BANK AND THE GAZA STRIP} GY UTIERS, PER PERSON FER DAD

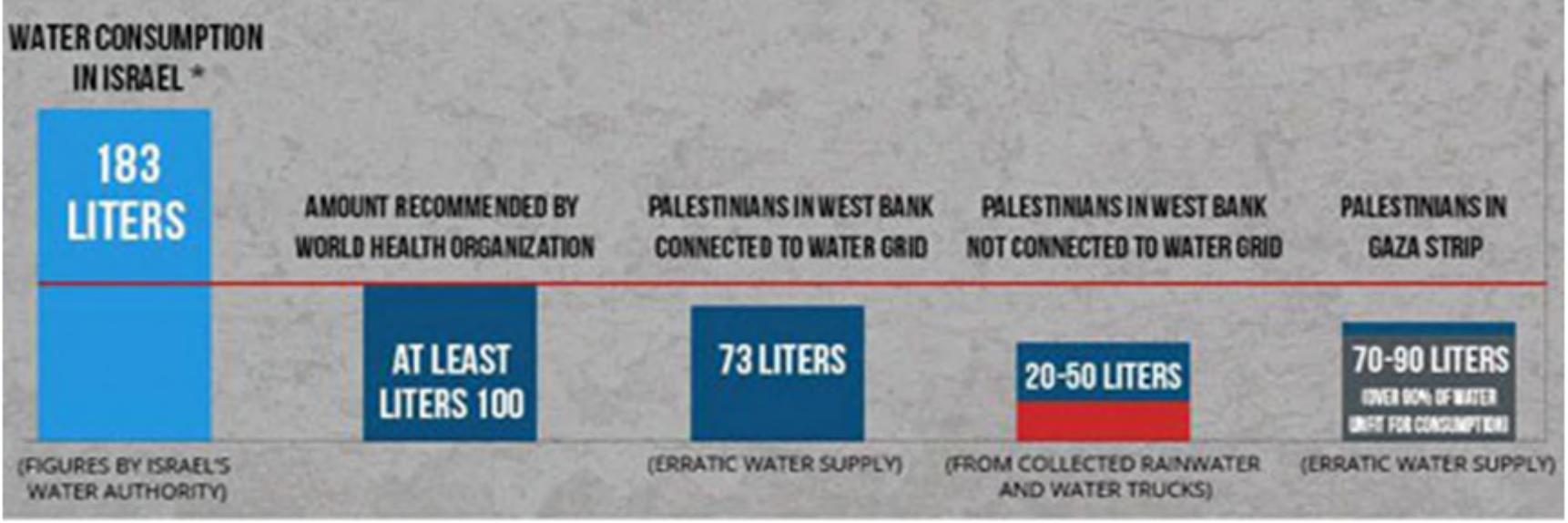

B'Tselem reports, "Throughout the summer months, hundreds of thousands of West Bank Palestinians suffer a severe shortage of water for personal consumption, bathing, cleaning, livestock and irrigation. This violates basic human rights, includ-

ing the right to health, decent housing, equality, and the benefit of natural resources. This is the result of Israel's policy since 1967, which is based on unfair allocation of water resources in the West Bank"[36]. It has been estimated that 50,000 Palestinians in 151 communities live on less than the World Health Organization's (WHO) recommendation of water per day necessary for basic survival ${ }^{[38]}$. The WHO recommends a minimum of 100 liters of water per person per day - this includes all water for drinking, cooking, bathing, and laundry. Mekorot reports average household water consumption in Israel to be between 100 and 230 liters per person per day. The West Bank per capita water consumption (per person / per day) is estimated at 73 liters. In early 2014, parts of East Jerusalem were without water for 3 months $^{[39]}$. Another consideration is desalination -removal of salt and other minerals from salt water to produce fresh water for human consumption or irrigation. Since this is a rainfall-independent water source and the climate in Palestine and Israel is dry, desalination from the Mediterranean Sea could ensure that Israel has enough water resources within internationally recognized borders. When desalination plants reach maximum production, then Lake Tiberius and West Bank Aquifers won't be as crucial to Israel's water supply. However, the price of water in Israel has steadily risen to cover desalination's high cost. Israel has opened four desalination plants in the last 9 years, providing approximately $35 \%$ of Israel's drinking water. By the year 2050, that number is expected to reach $70 \%{ }^{[40,41]}$. Also, fresh water that comes from desalinated seawater lacks minerals, particularly magnesium. These minerals are essential to human health and agricultural productivity ${ }^{[42]}$.

\section{Recent events that affect large agribusiness}

Dominance of large agribusiness hurts Palestinian farmers. The largest shares of international markets for grains, fertilizers, pesticides and seeds, are dominated by agribusiness giants Cargill, Nestle, Monsanto, ConAgra, and Archer Daniels Midland. These companies influence government food policy, squeeze out small farmers, promote energy-hungry industrial agriculture and create an unsustainable system of production and distribution. They also have a hand in Israeli food markets. Monsanto has a vegetable seeds division in Israel. Nestle has a research and development division in Sderot, a city in the western Negev in Israel's southern region - formerly the Palestinian village of Najd ${ }^{[43]}$.

The two biggest Israeli agricultural export companies, Mehadrin and Hadaklaim, benefit by establishing plantations and packing plants in illegal settlements. The Boycott, Divestment, and Sanctions (BDS) campaign advocates for food sovereignty in Palestine, by organizing boycotts of Israeli agricultural companies that grow and sell food from settlements. In February of 2013, 17 Palestinian organizations appealed to the international community to launch campaigns to end trade in produce from illegal settlements with Israeli agricultural companies that contribute to the destruction of Palestinian agriculture ${ }^{[44]}$. The same year, European solidarity networks, NGOs, and trade unions held demonstrations in Palestine and in 40 European cities. They protested the increase in international trade with Israeli agribusinesses that hurt Palestinian agriculture.

Farmers and activists in Gaza also marched towards the buffer zone near the Israeli border, where farmers must either abandon their land or face regular attacks and incursions by the Israeli military just to tend to their crops. Activists planted olive trees in Israeli razed farmlands and carried signs calling for a boycott of Israeli produce. Gaza fisherman also protested against regular Israeli military attacks that have continued despite the November 2012 ceasefire, allowing fishermen to fish up to six miles off Gaza's coast ${ }^{[45]}$.

In the wake of these recent conflicts, major Israeli food exporters faced an unprecedented wave of cancellations on orders from Europe. Food retailers in Scandinavia, the United 
Kingdom, France, Ireland, and Belgium all stopped orders of Israeli produce from illegal settlements. The major Israeli fruit companies, "EDOM" and "Priniv" also experienced boycotts, from European retailers. SuperValu, Ireland's largest grocery and food retailer and distributor reportedly removed Israeli products from their shelves in August 2014. The food retailer Tesco, in the UK, ceased stocking produce from illegal settlements or from companies that operate within them ${ }^{[46]}$. Agrexco, a partially state-owned Israeli business that exported $60-70 \%$ of the agricultural produce grown in Israel's illegal settlements, liquidated in 2011 after boycotts and campaigns in 13 European countries that caused retailers cut ties with the company. The BDS campaign has negatively affected the Israeli food companies, Mehadrin and EDOM. In 2014 Israeli settler leaders in the West Bank reported that the campaign has cost them \$29 million in lost sales ${ }^{[47]}$.

\section{Organizations working on solutions}

The UNRWA was established by the UN General Assembly 1949 to provide assistance and protection to the millions of registered Palestinian refugees. Its mission is to help Palestine refugees in Jordan, Lebanon, Syria, West Bank and the Gaza Strip to achieve their full potential. Financial support to UNRWA hasn't kept pace with increased demand for services caused by growing numbers of registered refugees amidst global conflict. The "General Fund" supporting UNRWA's core activities is heavily dependent on voluntary contributions. Currently the deficit stands at US\$ 68 million $^{[48]}$. Organizations like UNRWA can only provide short-term relief. The multi-faceted nature of food and water injustice in the West Bank and Gaza makes it difficult to find a longer-term solution. In addition to international organizations like the WFP and UNWRA, there are agencies, organizations, and campaigns working toward improving food and agriculture in the OPT.

A group of volunteers and agronomists established the Union of Agricultural Work Committees (UAWC) in 1986, as a non-profit organization. Based in Ramallah, West Bank, it began as a grassroots organization with a mission to "Empower small farmers, both men and women, as well as their families, and strengthen farmers' resilience on their lands in an agricultural and public developmental framework at the public level" ${ }^{\text {[49] }}$. UAWC was a recipient of the 2014 Food Sovereignty Prize at a ceremony on Wednesday, October 15, 2014, at Iowa State University ${ }^{[50]}$. The award was given on behalf of UACW's work to reclaim their human right to food. In his award acceptance speech, Mr. Ali Abd El Rahman, a Palestinian humanitarian aid expert and Chair of UAWC's Board of Directors, emphasized that Palestinians' biggest challenge Israel's control over Palestine's water supply ${ }^{[51]}$.

The overall objective of UAWC is to "improve food security and reduce poverty in vulnerable rural areas through comprehensive development of available agricultural sources, including land, water and human capacity"[52]. UAWC launches an annual olive harvest campaign using international volunteers, students, and academic activists to help reduce the risk of violence from Israeli settlers and from the army.

There is real potential for cooperation between parties in both Israel and Palestine. This was demonstrated in the 1994 Paris economic agreement, known as the Paris Protocol. For instance, fair exchange between Israeli and Palestinian-produced goods could actually be complementary, if Israel lifted water and land restrictions, and if there was a detailed analysis of what is produced on each side, and each side could produce what's lacking on the other. This type of cooperative agreement could benefit everyone. As long as inequity in the negotiation process exists, very little will change ${ }^{[53]}$.

The Palestine Agricultural Relief Committee (PARC), a leading non-profit, non-governmental organization involved in rural development, was established in 1983 by a group of agronomists. PARC works in development of rural areas with farmers in different sectors. This includes training and extension to small farmers and women in food processing and food security. They assist farmers with water harvesting from rain and provide olive oil nets, pruning materials, organic anti-fungal agents, and stainless steel tanks that can be used cooperatively between farmers. (Stainless steel is better than the more commonly used plastic to store olive oil, since what's stored in plastic declines in quality after 2 months). PARC provides a lab for small farmers to analyze and classify their olive oil. Farmers associated with PARC work collectively by bringing in their olives, weighing, collectively pressing, and storing the olives. PARC established "Al Reef for Investment \& Agricultural Marketing" as a marketing company to help Palestinian farmers to market their products locally and in the international market with high quality standards under the fair trade principle. The first company working on fair trade and marketing of Palestinian products, Al Reef analyzes samples and filters, bottles, and exports the olive oil. Palestinian Fair Trade olive oil sales are increasing in other countries including the United States. PARC has an "agricultural bank" that Al Reef finances. They can give short-term loans to some farmers.

UAWC and PARC are amongst the organizations that help implement the "One Million Tree Campaign" (MTC). Launched by the "Arab Group for Protection of Nature" founded in 2001, the MTC replants trees in Palestinian lands razed by Israeli bulldozers in areas where settlements have been built or expanded in the Occupied West Bank and Gaza Strip ${ }^{[54]}$. "Fair trade" originated in the 1980s as a way of supporting farmers in developing countries. A group of farmers, exporters, and cooperatives met in Jenin in 2004 to form the Palestine Fair Trade Association (PFTA) in 2004. It is now the largest fair trade producers' union. Palestinian olive oil was first awarded the fair trade mark in 2009, and is now distributed to over 17 countries around the world, including the United Kingdom, by companies such as Equal Exchange and Zaytoun ${ }^{[55]}$.

Palestinian entrepreneurs and NGO-sponsored agricultural experts are making olive oil a "distinctive," product and seek to find it as an "elite good" within a global space of circulation and distinction. Since the concept of fair trade promotes "ethical consumerism," connecting producer and consumer, Palestinian olive oil fits this model. Its high quality gives the olive oil some international recognition and, by proxy, increases consumers' awareness of the Palestinian plight ${ }^{[56]}$.

There is a Palestinian village, al-Walaja, which was re-established after the 1948 war on a mountain ridge overlooking remnants of the original village. The Israeli-West Bank separation wall isolates this village from Jerusalem and separates the residents from their farmland. Hundreds of olive trees were destroyed to make way for this barrier. An organization known as "Friends of al-Walaja" is a group of Jerusalem residents who regularly volunteer to help residents of this village with olive 
harvesting, planting trees, and getting to know the neighbors in order to unify the community and promote peace ${ }^{[57]}$.

There is also Sinokrot Global Group (SGG), founded in 1982, that focuses its investments on the growth centers of the Palestinian economy, including manufacturing, agriculture, and tourism, trade, and information technology. Sinokrot invests in olive mills and is engaged in trade with more than 30 countries throughout regional and global markets. One of their aims is to support a strong Palestinian economy by marketing Palestinian goods.

\section{Meeting basic nutritional needs in Palestine}

As economic and political constraints lead to food shortages, meeting basic nutritional needs becomes a serious challenge. A minimum number of daily calories are needed to sustain good health. As previously mentioned, the FAO of the UN has set minimum dietary energy requirements (MDER), expressed as kilocalories (kcal) per person per day. These are used exclusively to estimate the prevalence of undernourishment. Dietary energy requirements differ by gender and age, and for different levels of physical activity. Accordingly the MDER for light activity and minimum acceptable weight for attained-height, vary by country, and from year to year, depending on the population's gender and age structure. For an entire population, the minimum energy requirement is the weighted average of the minimum energy requirements of the different gender-age groups in the population. The FAO has calculated MDER for the
OPT at 1690 per person per day. This can be met with adequate access to nutritious food but diet is affected by the economy and

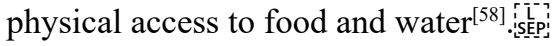

Many Palestinian food staples are low on the food chain. Lifting economic and political barriers could make these affordable and accessible. They provide adequate amounts of the macronutrients - protein, carbohydrate, and fat, and the key micronutrients - vitamin A, thiamin (vitamin $\mathrm{B}_{1}$ ), riboflavin (vita$\min \mathrm{B}_{2}$ ), niacin (vitamin $\mathrm{B}_{3}$ ), ascorbic acid (vitamin C), calcium, and iron.

Table 3 provides nutrition information on selected food sources typically found in Palestinian cuisine (lentils, fish, chickpeas, yogurt, pita bread, rice, oranges, dates, tomatoes, parsley, sesame tahini, and olives). Selection of these foods for analyses is based on foods from each food group: 1) protein (lentils, fish, chickpeas), 2) milk (yogurt), 3) grains (pita bread, rice), 4) fruits (oranges, dates), 5) vegetables (tomatoes, parsley), and 6) fats (sesame tahini, olives). Information for most is based on a 100gram (approximately 3 ounce) edible portion. For a few foods that are listed, information is based on a more typical portion size (e.g. 5 olives, one orange). Nutritional needs could easily be met with unrestricted access to these basic, nutrient-dense, relatively low cost foods. All provide varying amounts of the key nutrients.

Table 3: Nutritional values of selected staple foods - lentils, fish, chickpeas, yogurt, pita bread, rice, oranges, dates, tomatoes, parsley, sesame tahini, and olives.

Source: United State Department of Agriculture (USDA) Agricultural

research Service National Nutrient Database for Standard Reference 27 Software v.2.2.6. http://ndb.nal.usda.gov/ndb/search/list

\begin{tabular}{|c|c|c|c|c|c|c|c|c|c|c|c|c|}
\hline & $\begin{array}{l}\text { Lentils } \\
\text { boiled no } \\
\text { salt } 100 \mathrm{~g}\end{array}$ & $\begin{array}{l}\text { Fish, } \\
\text { sea } \\
\text { bass, } \\
\text { cooked } \\
100 \mathrm{~g}\end{array}$ & $\begin{array}{l}\text { Chick- } \\
\text { peas } \\
\text { (garban- } \\
\text { zo beans, } \\
\text { boiled, } \\
\mathbf{1 0 0 ~ g}\end{array}$ & $\begin{array}{l}\text { Yo- } \\
\text { gurt, } \\
\text { plain, } \\
4 \% \text { fat } \\
100 \mathrm{~g}\end{array}$ & $\begin{array}{l}\text { Whole- } \\
\text { wheat } \\
\text { pita } \\
\text { bread } \\
1-6.5 \text { “ } \\
\text { diameter }\end{array}$ & $\begin{array}{l}\text { Rice, } \\
\text { white, } \\
\text { medi- } \\
\text { um-grain, } \\
\text { cooked } \\
100 \mathrm{~g}\end{array}$ & $\begin{array}{l}\text { Orang- } \\
\text { es, raw, } \\
\text { navels, } \\
1 \text { or- } \\
\text { ange }\end{array}$ & $\begin{array}{l}\text { Dates, } \\
\text { pitted } \\
100 \mathrm{~g}\end{array}$ & $\begin{array}{l}\text { Toma- } \\
\text { toes } \\
\text { (red, } \\
\text { ripe) } 1 \\
\text { medium } \\
\text { whole }\end{array}$ & $\begin{array}{l}\text { Parsley } \\
\text { fresh } \\
100 \mathrm{~g}\end{array}$ & $\begin{array}{l}\text { Seeds, } \\
\text { sesame } \\
\text { butter, } \\
\text { tahini } \\
100 \mathrm{~g}\end{array}$ & $\begin{array}{l}\text { Olives } \\
\text { ripe (5 } \\
\text { black } \\
\text { olives) }\end{array}$ \\
\hline Calories & 116 & 124 & 164 & 88 & 170 & 130 & 69 & 277 & 22 & 88 & 570 & 80 \\
\hline Protein (g) & 9 & 24 & 9 & 3.5 & 6.3 & 2.38 & 1.2 & 1.18 & 1 & 2.97 & 18 & 0.65 \\
\hline $\begin{array}{l}\text { Carbohy- } \\
\text { drate (g) }\end{array}$ & 20 & 0 & 27 & 4.7 & 35 & 29 & 17.5 & 75 & 4.78 & 6.33 & 27 & 4.5 \\
\hline Lipids (g) & 0.4 & 2.56 & 2.6 & 3.3 & 1.6 & 0.21 & 0.21 & 0.15 & 0.2 & 0.79 & 48 & 7.2 \\
\hline $\begin{array}{l}\text { Vitamin A, } \\
(\text { RAE) } \mu \mathrm{g}\end{array}$ & 0 & 64 & 1 & 27 & 0 & 0 & 17 & 7 & 52 & 421 & 3 & 5 \\
\hline $\begin{array}{l}\text { Vitamin C } \\
(\mathrm{mg})\end{array}$ & 1.5 & 0 & 1.3 & 0.5 & 0 & 0 & 82 & 0 & 17 & 133 & 0 & 0 \\
\hline $\begin{array}{l}\text { Thiamin } \\
\text { (mg) }\end{array}$ & 0.17 & 0.13 & 0.12 & 0.03 & 0.34 & 0.17 & 0.09 & 0.05 & 0.05 & 0.09 & 1.23 & 0 \\
\hline $\begin{array}{l}\text { Riboflavin } \\
\text { (mg) }\end{array}$ & 0.07 & 0.15 & 0.06 & 0.14 & 0.08 & 0.02 & 0.07 & 0.06 & 0.02 & 0.10 & 0.51 & 0 \\
\hline $\begin{array}{l}\text { Niacin } \\
(\mathrm{mg})\end{array}$ & 1.06 & 1.9 & 0.53 & 0.07 & 2.84 & 1.83 & 0.59 & 1.61 & 0.73 & 1.31 & 5.92 & 0 \\
\hline $\begin{array}{l}\text { Calcium } \\
\text { (mg) }\end{array}$ & 19 & 13 & 49 & 121 & 15 & 3 & 60 & 64 & 12 & 138 & 420 & 5 \\
\hline Iron (mg) & 3.33 & 0.27 & 2.9 & 0.05 & 3.06 & 1.49 & 0.18 & 0.9 & 0.33 & 6.2 & 2.51 & 0.05 \\
\hline
\end{tabular}

Since olive oil is a primary fat in a typical Palestinian diet, it's worth emphasizing that Palestinian olive oil is rich in oleic acid. A group of Palestinian and Italian researchers examined virgin olive oils in the northern West Bank region (Salfit, Nablus, Qalqilya and Jenin), and found that they had an average of $70 \%$ oleic acid ${ }^{[59]}$. Oleic acid is one of the monounsaturated fatty acids that help to prevent blood cholesterol elevation - an important factor in heart disease prevention. Olive oil is also high in vitamin E, 
Farming, Water, Food Sovereignty, and Nutrition

one of the antioxidants that protect the lipids in human cell walls, hence defending against heart disease. The international olive oil council requires that olive oil be somewhere between 55 - 83\% monounsaturated ${ }^{[60]}$. Most Palestinian olive oil is 70 - $75 \%$ monounsaturated (oleic acid being the primary fatty acid).

Table 4 provides a sample 1690-calorie (FAO MEDR) menu based on typical foods available in Palestine. It is set up for a 30 - 50 year old adult weighing 150 pounds. It provides ample amounts of the key nutrients required for good health. Table 5 provides the nutrition information for this menu.

Table 4: Sample 1690 Calorie Menu.

\begin{tabular}{|c|c|c|c|}
\hline \multicolumn{4}{|c|}{ Breakfast ( $468.2 \mathrm{kcal}$ ) } \\
\hline 邻 & (1) & Falafel Patty & 3 item - 170 kcal \\
\hline 臬 & (i) & Tomatoes, Red & 1 item $-22 \mathrm{kcal}$ \\
\hline 旬 & (1) & Bread, Pita & 1 item $-165 \mathrm{kcal}$ \\
\hline 首 & (B) & Hummus & $0.25 \mathrm{c}-109 \mathrm{kcal}$ \\
\hline 可 & (i) & Coffee, Brewed & $8 \mathrm{fl} . \mathrm{oz} \cdot-2 \mathrm{kcal}$ \\
\hline \multicolumn{4}{|l|}{ Morning Snack } \\
\hline \multicolumn{4}{|c|}{ Lunch (470.5 kcal) } \\
\hline 忒 & b & $\begin{array}{l}\text { Tabouli, Tabbouleh or } \\
\text { Tabuli }\end{array}$ & $1 \mathrm{c} .-198 \mathrm{kcal}$ \\
\hline 可 & (i) & $\begin{array}{l}\text { Rice, White, Long Grain, } \\
\text { Boiled }\end{array}$ & $0.3 \mathrm{c} \cdot 52 \mathrm{kcal}$ \\
\hline 旬 & ( & $\begin{array}{l}\text { Beans, Broad or Fava, } \\
\text { Boiled }\end{array}$ & $0.3 \mathrm{c} .-56 \mathrm{kcal}$ \\
\hline 旬 & (1) & $\begin{array}{l}\text { Yogurt, Plain, Low Fat ( } 12 \\
\text { grams protein per } 8 \\
\text { ounces) }\end{array}$ & $1 \mathrm{c} .-154 \mathrm{kcal}$ \\
\hline \multicolumn{4}{|c|}{ Dinner (596.3 kcal) } \\
\hline 而 & (i) & $\begin{array}{l}\text { Bass, Sea Bass, Mixed } \\
\text { Species, Cooked, Dry Heat }\end{array}$ & $3 \mathrm{cz},-105 \mathrm{kcal}$ \\
\hline 向 & (2) & $\begin{array}{l}\text { CASBAH Lentil Pilaf, } \\
\text { Prepared }\end{array}$ & $0.5 \mathrm{c}-300 \mathrm{kcal}$ \\
\hline 向 & (3) & Tomatoes, Red & $3 \mathrm{sl} .-15 \mathrm{kcal}$ \\
\hline 而 & (i) & Lettuce, Looseleaf & $1 \mathrm{c} \cdot 5 \mathrm{kcal}$ \\
\hline 血 & (i) & $\begin{array}{l}\text { Olives, Jumbo or Super } \\
\text { Colossal }\end{array}$ & 3 item - 36 kcal \\
\hline 酩 & (3) & Cucumber, Sliced & $0.75 \mathrm{c} .12 \mathrm{kcal}$ \\
\hline 向 & (3) & oil, Olive & $1 \mathrm{~T} .-119 \mathrm{kcal}$ \\
\hline 向 & (3) & Juice, Lemon & $1 \mathrm{~T}_{\mathrm{C}}-3 \mathrm{kcal}$ \\
\hline \multicolumn{4}{|c|}{ Evening Snack (154.4 kcal) } \\
\hline 向 & (i) & $\begin{array}{l}\text { Yogurt, Plain, Low Fat (12 } \\
\text { grams protein per B } \\
\text { ounces) }\end{array}$ & $1 \mathrm{c} .-154 \mathrm{kcal}$ \\
\hline
\end{tabular}

Table 5: Nutrition Information - 1690 Calorie Menu.

Diet analysis program: Diet and Wellness Plus, Instant Access, 1st Edition, Cengage Learning (ISBN-10: 1-285-85620-1) 


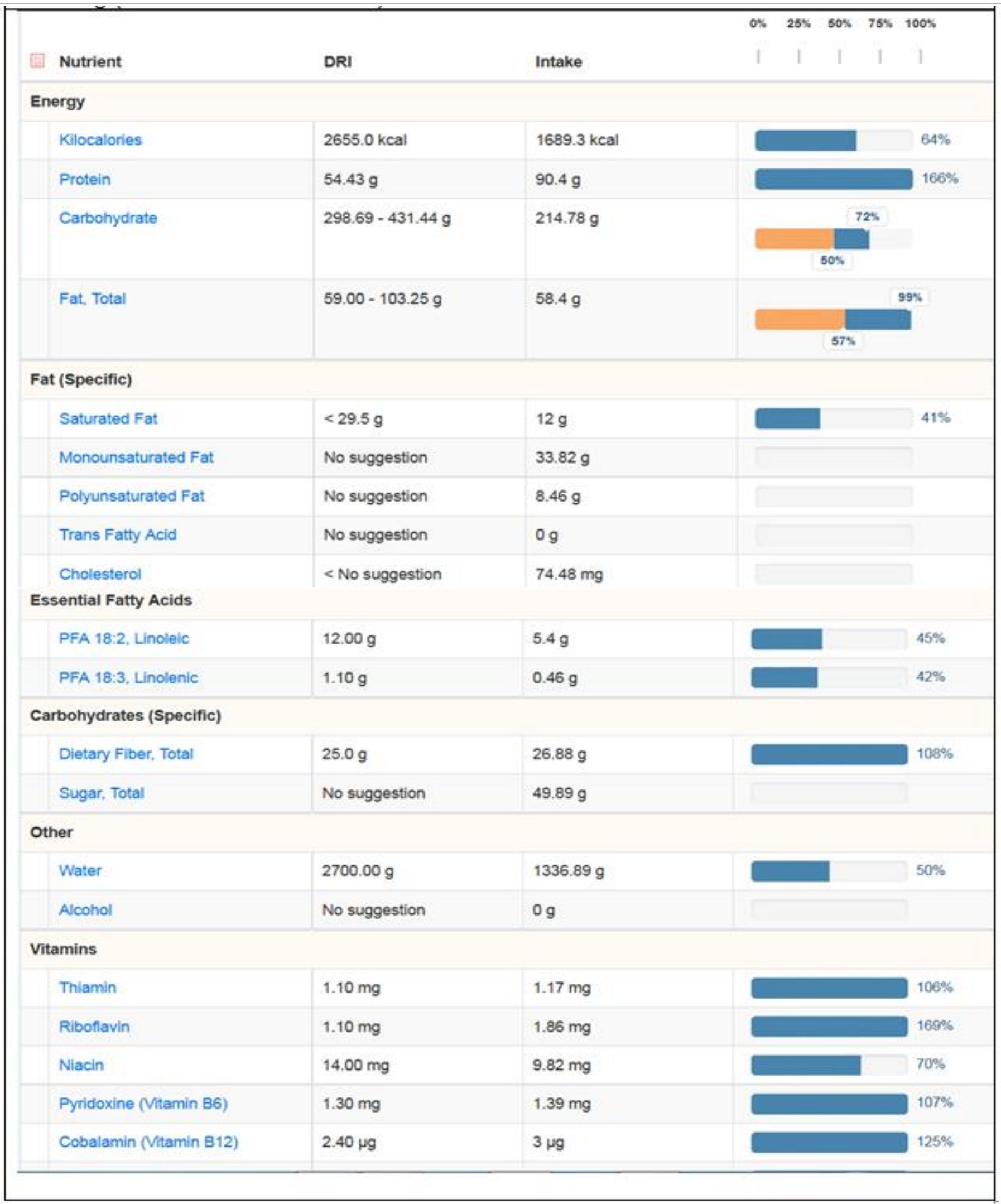

\section{Conclusions}

Emergency relief from the various aid organizations can only temporarily alleviate food insecurity and malnutrition, but can't provide sustainable food security nor lead to food sovereignty. Access to adequate water and food is the most basic human right. If farmers were empowered to improve their livelihoods, they'd first need to have the water restrictions lifted to access springs and underground water. Since they aren't allowed to dig wells they can't possibly access enough water for sustainable farming practices that could lift some barriers to food sovereignty. Small farmers also need government support and insurance to protect against 
disease and crop failure.

Desalination of water from the Mediterranean could potentially provide a source of water that's independent of the West Bank aquifers, but this process is not developed enough to be a widespread practice. As mentioned earlier, desalinated water lacks some minerals need for human health and for agricultural use, so more work is needed to develop desalination technology. tangible way to help alleviate poverty. It helps the Palestinian economy, and the oil is high quality, with its monounsaturated fatty acid content exceeding the average amount in olive oils from other regions.

Religion, national identity, and territorial clashes have created the never-ending disputes and inequality between the Israeli and Palestinian people. Palestinian farmers dream of the day that they will be allowed to reach and control their own borders, reduce the cost of import and exports, and produce better quality products without restriction. Widespread protests and the BDS campaign have fueled a greater public awareness of the Palestinian plight, particularly with regards to food and water justice. Since the European Union is the largest export market for Israeli goods, their recent actions against what they perceive as Israel's violation of human rights may be taking hold. The BDS campaign against Israeli agricultural trade is slowly impacting Israeli businesses. Until there is adequate food and water access to all of Palestine's population, there will be no peace and no food sovereignty. Greater international negotiations, along with continued pressure from the BDS movement are perceived as rays of hope for a better future in Palestine and Israel.

Those involved in improving food security for Palestinians need support in basic planning for meeting nutritional needs of the local population. Greater emphasis needs to be placed on the region's nutritious, staple foods that are low on the food chain. The sample menu and nutrition analysis is intended to meet the UN-FAO's MDER of $1690 \mathrm{kcal}$ per person per day for people in the Occupied Palestinian Territories. If some barriers to food access could be removed, food variety could be increased, and food plans meeting this baseline caloric and nutrient requirement would be within reach.

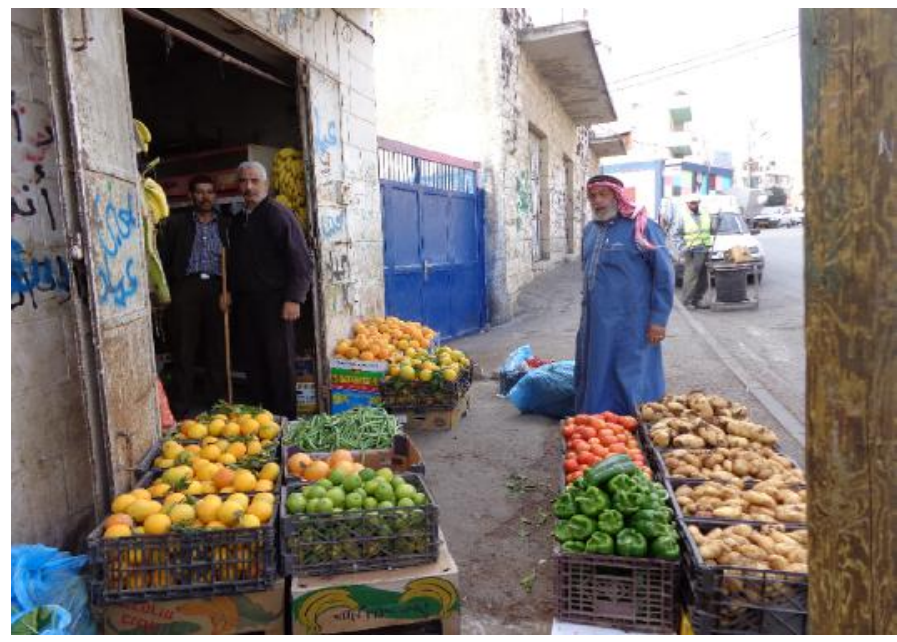

Farmstand:

\section{References}

1. Fairbairn, M. Farming transformation: the counter-hegemonic potential of food sovereignty in the US context. (2012) Agriculture and Human Values 29 (2): 217-230.

2. Behnassi, M., Yaya, S. Land Resource Governance from a Sustainability and Rural Development Perspective. In: Behnassi Mohamed (eds), Sustainable Agricultural Development: Recent Approaches in Resources Management and Environmentally-Balanced Production Enhancement New York: (2011) Springer 2-23.

3. El, Krunz, Sa'adi, Al Quds University, Abu Dis, West Bank, Palestine. (Personal communication, November 18, 2013).

4. Tolan, S. The Lemon Tree: An Arab, a Jew, and the Heart of the Middle East. (2006) New York: Bloomsbury Publishers.

5. Qumsiyeh, M.B. Popular Resistance in Palestine: A History of Hope and Empowerment. (2011) Pluto Press.

6. Peters, J., Newman, D., The Routledge Handbook on the Israeli-Palestinian Conflict. (2103) London \& New York: Taylor and Francis Group. 6

7. Nusseibeh, S (2007). Once upon a country: A Palestinian life. New York: Picador.

8. Elgindy, Khaled, "Oslo's 20-year legacy of failure lives on." (2013, September 13). Retrieved December 1, 2014

9. Israeli settler state created in West Bank, East Jerusalem: REPORT. (2016).

10. Kannan, A. Desertification, Land Grabbing and Food Sovereignty: the Unexplored Link. (2013). Science, Technology and Arts Research Journal 2(2): 153-159.

11. Agricultural Development, Food Security Unattainable without Self-Determination, Sovereignty of Palestinian People, Speakers Say in Second Committee (2014).

12. Food Insecurity in Palestine Remains High, UNRWA. (2014).

13. Massad, S., Holleran, S., Gebre-Medhin, M., et al. Double burden of undernutrition and obesity in Palestinian schoolchildren: a crosssectional study. (2012) Lancet 380: S5-S6.

14. State of Palestine. (n.d.). Retrieved January 30, 2014.

15. Kampschoer, c. How WFP Brought Food and Hope to Gaza's Battered Communities. (2014). World Food Programme.

16. Staudacher, K., Schallhart, N., Thalinger, B., et al . (2013) Plant diversity affects behaviour of generalist root herbivores, reduces crop damage, and enhances crop yield. Ecol Appl 23 (5): 1135-1145.

17. Abdelnour, S., Tartir, A., Zurayk, R.. Farming Palestine for Freedom. (2012) Policy Brief.

18. Exporting And Importing Via Jordanian and Israeli Ports: Comparison Study, Trade Corridors' Facilitation Project Phase II. (2013). Palestine Trade Center.

19. Sansour, V., Tartir, A. Palestinian Farmers: A Last Stronghold of Resistance. (2014) Policy Brief.

20. Land Expropriation and Settlements. (2015) B'Tselem.

21. Israel Moves to Make its Biggest Land Grab in 30 Years, in Palestine's West Bank. (2014) Global Voices

22. The Separation Barrier. (2011) B'Tselem

23. Tamimi, A.A. Socioeconomic and environmental impacts of the Israeli Separation Wall. (2011). International Journal of Environmental Studies 68(4): 557-564.

24. Israeli warships open fire at fishermen off Gaza coast. (2014). MA'AN NEWS AGENCY

25. Palestine Before 1947, by Refaat M. Loubani (2001).

26. Olive Harvest Fact Sheet. (2012, October) Retrieved October 2, 2014.

27. Jaffa, the orange's clockwork [Motion picture]. (2010) Momento

28. Israel is uprooting West Bank's future (2015) The New Arab

29. Israel settlers uproot Palestine trees. (2014, April 22) Retrieved December 10, 2014.

30. Olive trees uprooted in West Bank 'price tag' attack. (2014, May 3) Retrieved December 20, 2014. 
31. Israeli settlers accused of destroying Palestinian olive trees, Al Jazeera America. (2013). Retrieved December 13, 2014.

32. 'Today at 0800 , Israeli bulldozers came to the fertile valley where we planted fruit trees--'(2014, May20) Retrieved December 13, 2014.

33. Israeli Settlers Uproot 750 Grape Vines near Bethlehem. (2014 April 5) Retrieved December 17, 2014.

34. Mehta, L., Veldwisch, G.J., Franco, J. Water grabbing: Focus on the (re)appropriation of finite water resources. (2012) Water Alternatives 5(2): 193-207.

35. Gasteyer, S., Isaac, J., Hillel, J., et al. Water grabbing in colonial perspective: Land and water in Israel/Palestine. (2012) Water Alternatives 5(2): 450-468.

36. Background: Water crisis. (2014, February 25). Retrieved December 7, 2014.

37. Discriminatory water supply. (2014, March 10). Retrieved December $1,2014$.

38. How much water is needed in emergencies? (n.d.). Retrieved January 13,2015

39. Three months without water in parts of East Jerusalem. (2014, March). Retrieved December 16, 2014.

40. Brenner, Y. Is Desalination the Answer? (2010, August 12) Retrieved January 13, 2015.

41. Israel's desalination program averts future water crises. (2014).

42. Avni, N., Eben-Chaime, M., Oron, G. Optimizing desalinated sea water blending with other sources to meet magnesium requirements for potable and irrigation waters. (2013) Water Res 47(7): 2164-2176.

43. Global Policy Forum. (2014).

44. Farming Injustice: International trade with Israeli agricultural companies and the destruction of Palestinian farming. (2013) Palestinian farming and civil society organizations.

45. Mobilizations in Palestine and across Europe as activists call for boycott of Israeli agribusinesses. (2013).
46. Ireland's biggest food retailer drops Israeli produce, as European boycotts surge. (2014).

47. Jordan Valley settlements hit by boycott campaign. (2014).

48. US Increases Support for UNRWA. (2014).

49. Our Mission - About Us - UAWC (2012).

50. Food Sovereignty Prize to be awarded October 15th at Iowa State Historical Building. (2014).

51. Palestinian Farmer Spotlights Food Sovereignty. (2014) The Progressive.

52. Land Reclamation. (2014) UAWC.

53. Dagahmeh, Ayman, Project Manager, United Agricultural Work Committees (October 29, 2013, Personal communication).

54. Towards people's sovereignty over food and natural resources. (2014).

55. Emily Lawrence. Fair trade helps Palestinian farmers stay on their land. (2013).

56. Meneley, A. Discourses of Distinction in Contemporary Palestinian Extra-Virgin Olive Oil Production. (2014) Food and Foodways 22(1-2): 48-64.

57. Israeli friends of Palestinian village. (2013).

58. FAO methodology for the measurement of food deprivation. (2008). 59. Abu Reidah, I.M., Yasin, M., Urbani, S., et al. Study and characterization of Palestinian monovarietal Nabali virgin olive oils from northern West Bank of Palestine. (2013) Food Research International 54(2): 1959-1964.

60. Moreno Esteban, B., Lezcano Solís. A. Olive oil: a cornerstone of the Mediterranean diet. (2015) Official Journal of the International O1ive Council 121: 19-25.

61. U.S. Department of State, Diplomacy in Action: Executive Summary. (2014).
Online ISSN: 2377-0619

Journal Title: International Journal Food and Nutritional Science Journal Short Name: Int J Food Nutr Sci
Ommega Online Publishers

E-mail: foodscience@ommegaonline.org

Website: www.ommegaonline.org 